\title{
Recenzja książki: Friedemann Schulz von Thun Sztuka Rozmawiania. Analiza zaburzeń
}

\author{
Wojciech Laskowski \\ Instytut Filozofii, Uniwersytet im. Adama Mickiewicza \\ ul. Szamarzewskiego 89c, 60-569 Poznań
}

Recenzowana książka jest pierwszą z serii „Sztuka Rozmawiania”. ${ }^{1}$ Publikacja jest poświęcona analizie zaburzeń komunikacji, a jednocześnie stanowi wprowadzenie do autorskiej koncepcji komunikacji międzyludzkiej, którą Friedemann Schulz von Thun konsekwentnie rozwija w pozostałych pracach (Schulz von Thun 2007a; 2007b;. 2007c)

Pomimo tego, że książka została wydana już w 1981 roku, polskiemu Czytelnikowi znana jest dopiero od kilku lat. Prace niemieckiego specjalisty od komunikacji społecznej cieszą się w Polsce coraz większym zainteresowaniem. Niedawno pojawiło się wznowienie całej serii - wydane przez Wydawnictwo WAM. Warto zatem przyjrzeć się bliżej walorom pracy Schulza von Thuna. Niniejsza recenzja może szczególnie zainteresować dopiero co rodzącą się grupę polskich badaczy komunikacji społecznej.

Friedmann Schulz von Thun jest profesorem i wykładowca psychologii na uniwersytecie w Hamburgu. Warto jednak podkreślić, że Schulz von Thun, oprócz pracy naukowo-dydaktycznej, posiada również bogaty dorobek zawodowy jako trener komunikacji interpersonalnej. W związku z tym teoria autora była konfrontowana przez niego przez wiele lat $\mathrm{z}$ obserwacjami jego kursantów. Część z nich została wykorzystana do zilustrowania konkretnych fragmentów jego teorii.

Teoretyka komunikacji szczególnie zainteresują główne założenia. Oto rekonstrukcja zasadniczych tez jego pracy:

1. Komunikacja jest wielofunkcyjna! Konkretniej: komunikat ma kilka płaszczyzn jednocześnie! [Patrz: cztery aspekty wypowiedzi: rzeczowy, relacyjny, ujawniania siebie i apelowy]

2. Ta wielopłaszczyznowość jest możliwa m.in. dzięki temu, że odbywa się za pomocą różnych znaków - środków komunikacyjnych! [Patrz: Komunikacja werbalna i niewerbalna]

3. Dwa podstawowe poziomy komunikatu - tj. werbalny i niewerbalny - zwykle się uzupełniają (dopełniają / interpretują wzajemnie / są ze sobą spójne). Bywa jednak i tak, że się kłócą! [Patrz: spójność i niespójność w komunikacji]

4. Pomimo tej całej różnorodności środków komunikacyjnych - komunikaty mają swoją stronę pierwszoplanową i drugoplanową! [Patrz: komunikacja wprost i nie wprost]

5. Komunikacja wprost odbywa się za pomocą słów, natomiast nie wprost na dwa sposoby: poprzez komunikację niewerbalną i/lub poprzez efekt scalania przez odbiorcę informacji przesłanych z już posiadanymi (np. jakimiś schematami, skryptami poznawczymi)

6. Komunikacja nie wprost i związana $\mathrm{z}$ nią warstwa „nierzeczowa” jest istotniejsza dla przebiegu i wyniku interakcji!

7. Wprost (jak i nie wprost) może być przekazana każda płaszczyzna komunikacji (tj. każda funkcja - ujawnianie siebie, przekaz treść, apel, budowanie relacji)!

\footnotetext{
${ }^{1}$ Pozostałe tomy to kolejno: Rozwój osobowy, Dialog wewnętrzny, W porozumieniu ze sobą i innymi.
} 
Sercem książki jest kwadratowy model komunikacji. Dzięki temu modelowi cała książka (a także kolejne jego tomy) zyskuje na przejrzystości. Każda płaszczyzna wypowiedzi została omówiona w oddzielnym rozdziale.

Warto zwrócić uwagę na jasno postawiony przez autora problem: jak poprawić komunikację międzyludzką? (Innymi słowy: jak postępować z innymi i jak postępować z samym sobą?) Czytelnik otrzymuje także konkretną odpowiedź, która z każdym kolejnym rozdziałem staje się coraz bardziej przekonująca! Przesłanie książki brzmi następująco - staraj się uzyskać 'kwadratową klarowność'! Dobra komunikacja to bowiem komunikacja czterowymiarowa (pełna; żywa; przejrzysta i spójna). Odnosząc to do modelu kwadratowego uzyskujemy konkretne wskazówki praktyczne:

$>$ na płaszczyźnie rzeczowej - bądź zrozumiały, tj. mów prosto, zwięźle, w sposób uporządkowany (logiczny) i barwny (patrz: hamburska koncepcja zrozumiałości2)

$>$ na płaszczyźnie ujawniania siebie - stawiaj na autentyczność połączoną z wyczuciem sytuacji (tzw. współbrzmienie)

$>$ na płaszczyźnie relacyjnej - okazuj szacunek i przyznaj innym prawo do podejmowania samodzielnych decyzji (styl partnerski)

$>$ na płaszczyźnie apelowej - korzystaj z komunikacji otwartej (patrz: apel otwarty)

To rzeczywiście „magiczny kwadrat”, jak pisze o nim sam autor, bowiem spełnia kilka zadań:

$>$ po pierwsze stanowi ciekawą propozycją klasyfikacji funkcji mowy - bowiem wskazuje na najczęściej wymieniane przez specjalistów zadania języka (funkcja ekspresywna, interpersonalna, opisowa i apelowa) i dodatkowo zakłada ich współwystępowanie w każdym komunikacie

$>$ po drugie porządkuje główne zagadnienia komunikologiczne (tj. jak być zrozumiałym, jak mówić o sobie, jak budować relacje i jak być skutecznym)

$>$ po trzecie jest doskonałym narzędziem diagnostycznym - pozwala na precyzyjną analizę wypowiedzi i diagnozę problemów komunikacyjnych

Istotne $\mathrm{w}$ teorii Schulza von Thun jest również omówienie komplementarnej względem nadawania komunikatu - umiejętności słuchania. Słuchanie, o którym tak wiele już powiedziano, w świetle modelu kwadratowego nabiera nowego znaczenia. Cóż bowiem znaczy słuchać aktywnie, czy też uważnie? W świetle koncepcji Schulza von Thun - słuchać znaczy korzystać z czterech uszu (odpowiednio względem czterech warstw wypowiedzi) - ucha rzeczowego i relacyjnego i diagnostycznego $\mathrm{i}$ apelowego! Takie uwrażliwienie $\mathrm{w}$ odbiorze wzbogaca komunikację i poprawia jej jakość.

Oprócz wskazań dotyczących poprawy jakości komunikacji, autor, niejako dla przeciwwagi omawia również niezwykle ważny temat metakomunikacji. Mówienie o komunikacji jest narzędziem do poprawiania „chorej” komunikacji. Ta sugestia w literaturze przedmiotu jest dobrze znana i omówiona - podstawową funkcją metakomunikacji jest naprawianie tego, co źle poszło. To swoiste lekarstwo na złą komunikację.

Podsumowując swoje rozważania, Schulz von Thun kieruje uwagę czytelnika na, jego zdaniem, fundamentalną antynomię w komunikacji międzyludzkiej. Chodzi o dwie strony komunikacji: wyrażanie-działanie. Ma to związek z niezwykle ważkim problemem, czy też napięciem towarzyszącym każdej komunikacji - czy mam być autentyczny (szczery, rzeczowy) czy też skuteczny? (Inaczej: czy mam się skupić na opisywaniu rzeczywistości czy też na wpływaniu na nią?) Istotną zasługą autora jest to, że nazywa ten problem i proponuje swoje wyważone stanowisko. Dla każdego, kto zetknął się z filozofią skuteczności (którą autor nazywa filozofią „odpowiedniego opakowania”), a także z filozofią szczerości, koncepcja współbrzmienia Schulza von Thun stanowi ciekawą propozycję alternatywna..3 $\mathrm{Na}$ czym ona polega? Według

\footnotetext{
${ }^{2}$ Szczegółowe omówienie tego modelu można znaleźć w książce „Wyrażać się zrozumiale” (Schulz von Thun F., Langer I., Tausch R., Wyrażać się zrozumiale, Wydawnictwo WAM, Kraków 2004.)

${ }^{3}$ Wprowadzam tutaj rozróżnienie na trzy główne podejścia do komunikacji międzyludzkiej, z którymi można się spotkać w literaturze przedmiotu: filozofia skuteczności (np. reprezentowana przez Josefa Kirschnera, autora poradnika „Manipulować - ale jak?”), filozofia szczerości (np. reprezentowana przez Brada Blantona, autora książki „Radical Honesty") i filozofia współbrzmienia (korespondująca z założeniami teorii asertywności i koncepcją F. Schulza von Thun - patrz: „Sztuka Rozmawiania” Część 3).
} 
autora dobra komunikacja jest wynikiem podwójnej spójności - po pierwsze zgodności z samym sobą (wewnętrzne samopoczucie, cele, przekonania itd.), po drugie zgodności z sytuacją zewnętrzną (kondycja rozmówcy, przyjęte role, itd.).

„Sztuka Rozmawiania” Schulza von Thun jest z pewnością doskonałym podręcznikiem komunikacji międzyludzkiej. Otwierając tę książkę można mieć dwa oczekiwania: znalezienie rzetelnych naukowych wyjaśnień i/lub praktycznych porad. Dostajemy i jedno i drugie. O ponadprzeciętnych walorach recenzowanej tu książki stanowią także: jej aktualność i oryginalność. Uznanie budzi również jej logiczna struktura. Autor udowadnia, że jego model sprawdza się - i udowadnia to swoim własnym piórem. Jego język jest niezwykle zrozumiały, a oczekiwania są wyrażane otwarcie. Schulz von Thun uwiarygodnia się również dzięki szczerym i nie jednokrotnie autokrytycznym opowieściom. Czytając go łatwiej nam przyjać jego kierownictwo jako mentora $\mathrm{w}$ nowo powstałej relacji (uczeń-czytelnik - nauczyciel-autor). Patrząc z tego punktu widzenia Schulz von Thun to reprezentant nowoczesnych komunikatorów - specjalistów w trudnej sztuce, którą każdy praktykuje, a nawet o której każdy może coś powiedzieć, jednak tylko nieliczni robią to kompetentnie.

Pomimo niezaprzeczalnych zalet modelu kwadratowego, Czytelnik o zaawansowanej wiedzy komunikologicznej czy językoznawczej może czuć pewien niedosyt. Autor nie odnosi się bowiem do bogatej dyskusji na temat funkcji mowy. Nie znajdziemy tu również szczegółowych ustaleń w kwestii tego, jak realizowane są poszczególne funkcje wypowiedzi, a także brakuje wyjaśnień tego, jak to jest możliwe jednocześnie.

Na koniec, warto również zwrócić uwagę na zmienioną szatę edytorską nowego wydania serii „Sztuka Rozmawiania”. Wprowadzone symbole graficzne ułatwiają przyswajanie nowych treści, gdyż spełniają (zwykle pomijaną w tekstach naukowych) funkcję fatyczną, ekspresywną i perswazyjną. Można powiedzieć, że wypełniają one lukę, jaką tworzy brak autora w procesie nabywania wiedzy. Prawdopodobnie te i inne zabiegi staną się nie długo normą.

$\mathrm{Z}$ pełnym przekonaniem recenzowaną książkę można zarekomendować wszystkim Czytelnikom zainteresowanym problematyką komunikacji międzyludzkiej, zarówno teoretykom, jak i praktykom. 


\section{Bibliografia}

Schulz von Thun, F. 2007a. Sztuka Rozmawiania. Analiza zaburzeń. Kraków: Wydawnictwo WAM. Schulz von Thun, F. 2007b. Sztuka Rozmawiania, Rozwój osobowy. Kraków: Wydawnictwo WAM. Schulz von Thun, F. 2007c. Sztuka Rozmawiania, Dialog wewnętrzny. Kraków: Wydawnictwo WAM. Schulz von Thun, F., Langer I., Tausch R. 2004. Wyrażać się zrozumiale. Kraków: Wydawnictwo WAM. Kirschner, J. 1994. Manipulować - ale jak? Warszawa: Wydawnictwo SOKRATES. 